\title{
The Correlation between Pituitary Gonadotrophins, Gonadal Sex Steroid Hormone with Ferritin Level in Pubertal Females with Thalassemia Major at Wassit Province - Iraq 2020
}

\author{
Ahmed Ansaf ${ }^{1}$ iD, Safaa A. Faraj ${ }^{1 *}$ (i), Safa Kazem² \\ ${ }^{1}$ Department of Pediatrics, College of Medicine, Wasit University, Al Kut, Wasit, Iraq; ${ }^{2}$ Department of Urology and Infertility, \\ Al-Sader General Teaching Hospital, Amarah, Iraq
}

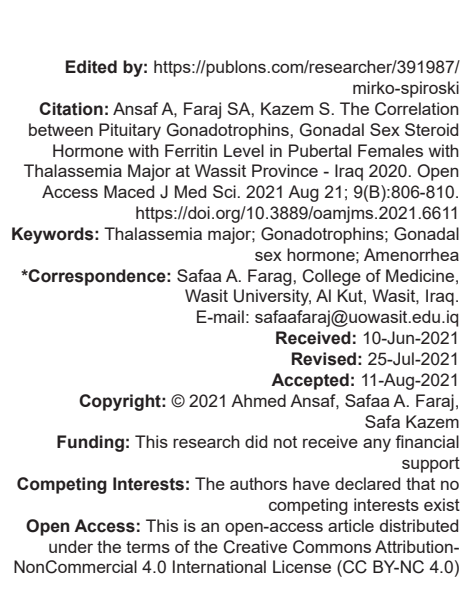

\section{Introduction}

Unfortunately, till the time of the study, the new patients registered in Al-Kut blood disease center increasing every day to reach more than five hundred and fifty patients. The absence of governmental health attention for premarriage screen greatly affects this increase.

However, beta thalassemia major (BTM) is the most frequent hemoglobinopathy worldwide [1].

It requires long-term life-saving blood transfusion with monitored chelation therapy [2], [3]. As a consequence, secondary hemosiderosis could results in significant morbidity, especially to the heart, liver, and endocrine glands from excess iron [4], [5].

Endocrine dysfunction has been reported as earliest organ toxicity seen in iron-overloaded participants with thalassemia [6]. Hypogonadism is the most common endocrine complication affecting $50 \%-100 \%$ of thalassemia major patients in various populations leading to low quality of life [1], [4].

In addition to delayed puberty and arrest of sexual development (gonadal failure) can leads to short stature, and osteoporosis accompanied with a burden psychological impacts and low self-steam [6].

The clear view about gonadal failure in BTM is iron deposited mainly in the pituitary gonadotrophic cells which leads to disruption of gonadotropin (luteinizing hormone $[\mathrm{LH}]$ and follicle-stimulating hormone [FSH]) and to less extent iron deposited on gonadal organ as the majority of affected female can still ovulate after hormonal treatment [1], [5].

With improvement of life expectancy for these patients making the concern for fertility and pregnancy to gain increasing importance. In Al-Kut hereditary blood disease center at the South of Iraq, despite the recent use of oral (X-Jade) and the old subcutaneous 
(Desferal) iron-chelating agents, still the maintenance, availability, and compliance for these agents are the major etiologies for poor control iron overloads.

Early diagnosis and treatment of gonadal failure have a particular importance for getting the phenotype to be normal women and maintaining normal genital tract and future fertility. In this study, we try to correlate the pituitary gonadotrophin and gonadal sex steroid hormone in pubertal thalassemic female with ferritin level.

\section{Patients and Methods}

A cross-sectional study on 41 female patients at pubertal age (13-45 years) randomly selected study with regular blood thalassemia major disease registered in Al-Kut Hereditary Blood Disease Center in the South of Iraq. The samples were collected from June to August 2020.

After taking ethical clearance from the center and a written consents from the patients or taking care persons involved in this study. Demographic data were evaluated including (the age, type of chelation therapy, compliance for treatment and pretransfusion mean hemoglobin levels, and presence of amenorrhea). Biochemical investigation for serum ferritin, $\mathrm{FSH}$, LH, and estrogen levels was done at the time of the study at the laboratory of the center by Vidas machine.

Other hereditary blood disease and newly diagnosed thalassemia major patients were excluded from this study. Statistical analysis was performed using the SPSS software version 20 with $p<0.05$ regarded as significant. The correlation between serum ferritin and $\mathrm{FSH}, \mathrm{LH}$, and estrogen levels done by person correlation.

\section{Results}

The demographic data of patients who enrolled in this study are shown in Table 1. Twenty-four patients were $<20$ years of age, and seventeen patients were more or equal to 20 years. Regarding iron chelator, more than $24(58 \%)$ of the patients were on exjade therapy. Only twenty-three of forty-one patients have good compliance history of an iron chelator. Most of the patients $33(80.5 \%)$ were suffering from primary amenorrhea, and only six patients $(14.6 \%)$ were with a history of normal menstrual cycle patterns. Twentysix $(63.4 \%)$ patients had serum ferritin levels of more than $3000 \mathrm{ng} / \mathrm{dl}$. Thirty patients presented with $\mathrm{Hb}$ level $<10 \mathrm{~g} / \mathrm{dl}$ at the time of the study carry out.
Table 1: Demographic data of the patients

\begin{tabular}{lll}
\hline Item & No & Frequency \\
\hline Age group & & \\
$\quad<20$ years & 24 & 58.5 \\
$\quad$ Equal or more than 20 & 17 & 41.5 \\
$\begin{array}{l}\text { Chelator types } \\
\quad \text { Desferal }\end{array}$ & 17 & 41.5 \\
$\quad$ Exjad & 24 & 58.5 \\
$\begin{array}{l}\text { Compliance to iron chelator } \\
\quad \text { Good }\end{array}$ & 23 & 56.1 \\
$\quad$ Bad & 18 & 43.9 \\
Menstrual cycles pattern & & \\
$\quad$ Normal & 6 & 14.6 \\
$\quad$ Primary amenorrhea & 33 & 80.5 \\
$\quad$ Scanty & 2 & 4.9 \\
Ferritin level group & 15 & 36.6 \\
$\quad \leq 3000$ ng/dl & 26 & 63.4 \\
$\quad$ More than 3000 ng/dl & & \\
Hb level group & 30 & 73.2 \\
$\quad<10$ g/dl \\
equal or more than 10 g/dl & 11 & 26.8 \\
\hline
\end{tabular}

The descriptive data of the patients are shown in Table 2; the mean age was 20.6 years with a range from 14 to 43 years. The mean of serum ferritin was $4871 \mathrm{ng} / \mathrm{dl}$, the lowest level was $417 \mathrm{ng} / \mathrm{dl}$ while the highest level was $11094 \mathrm{ng} / \mathrm{d}$. The mean FSH level was $1.7 \mathrm{IU} / \mathrm{mL}$, the mean level of $\mathrm{LH}$ was $1.2 \mathrm{lU} / \mathrm{L}$, and the mean level of estrogen was $24 \mathrm{pg} / \mathrm{ml}$, regarding the mean hemoglobin level was $8.8 \mathrm{~g} / \mathrm{dl}$ with a range (7-10) $\mathrm{g} / \mathrm{dl}$.

Table 2: Age and laboratory data of the patients

\begin{tabular}{llllll}
\hline Item & No & Minimum & Maximum & Mean & SD \\
\hline Age in years & 41 & 14 & 43 & 20.6 & 6.0 \\
S. ferritin ng/dl & 41 & 417 & 11094 & 4871.3 & 3378.8 \\
$\mathrm{FSH} \mathrm{mlU/mL}$ & 41 & 0.10 & 4.6 & 1.7 & 1.1 \\
LH IU/L & 41 & 0.10 & 3.4 & 1.2 & 0.9 \\
Estrogen pg/mL & 41 & 7.0 & 64.4 & 24.0 & 14.9 \\
Prolactin ng/mL & 41 & 5.8 & 55.0 & 21.9 & 10.1 \\
Hb g/dl & 41 & 7 & 10 & 8.85 & 0.8 \\
\hline LH: Luteinizing hormone, FSH: Follicle-stimulating hormone.
\end{tabular}

The correlation between serum ferritin and the hormone level that affects the state of puberty in patients is shown in Table 3. Regarding the FSH level, there was a statistically significant difference between the groups with a serum ferritin level $\leq 3000 \mathrm{ng} / \mathrm{del}$ and group with serum ferritin levels more than $3000 \mathrm{mg} / \mathrm{dea}$ with $p$-value 0.001 , as a group with serum ferritin levels more than $3000 \mathrm{mg} /$ del were with low degree of $\mathrm{FSH}$ level as compared to another group.

Table 3: hormonal level according to serum ferritin level

\begin{tabular}{llllll}
\hline Item & Serum ferritin group & $\mathrm{n}$ & Mean & $\mathrm{SD}$ & $\mathrm{p}$-value \\
\hline FSH & $\leq 3000 \mathrm{ng} / \mathrm{dl}$ & 15 & $2.5 \mathrm{mlU} / \mathrm{mL}$ & 1.1 & 0.001 \\
& $>3000 \mathrm{ng} / \mathrm{dl}$ & 26 & $1.2 \mathrm{mlU} / \mathrm{mL}$ & 0.7 & \\
$\mathrm{LH}$ & $\leq 3000 \mathrm{ng} / \mathrm{dl}$ & 15 & $1.8 \mathrm{IU} / \mathrm{L}$ & 0.9 & 0.002 \\
& $>3000 \mathrm{ng} / \mathrm{dl}$ & 26 & $0.8 \mathrm{IU} / \mathrm{L}$ & 0.8 & \\
\multirow{2}{*}{ Estrogen } & $\leq 3000 \mathrm{ng} / \mathrm{dl}$ & 15 & $37.2 \mathrm{pg} / \mathrm{mL}$ & 14.6 & 0.003 \\
& $>3000 \mathrm{ng} / \mathrm{dl}$ & 26 & $16.4 \mathrm{pg} / \mathrm{mL}$ & 8.4 & \\
\multicolumn{2}{l}{ LH: Luteinizing hormone, $\mathrm{FSH}$ : Follicle-stimulating hormone. }
\end{tabular}

A low average serum LH concentration (0.8 IU/L) was observed in the group with elevated serum ferritin compared to the group with low serum ferritin (1.8 IU/L), with a statistically significant p-value, 0.002. A low mean serum LH concentration $(0.8 \mathrm{IU} / \mathrm{L})$ was observed in the group with elevated serum ferritin as compared to the group with low serum ferritin $(1.8 \mathrm{IU} / \mathrm{L})$, with a statistically significant p-value, 0.002 .

A low mean serum estrogen concentration (16.4 pg/ml) was observed in the group with elevated 
serum ferritin as compared to the group with low serum ferritin $(37.2 \mathrm{pg} / \mathrm{ml})$, with a statistically significant p-value, 0.003 .

The correlation between serum ferritin of all patients with FSH was inverse, Pearson's correlation $(-0.4)$ and $p$-value 0.0009, as shown in Figure 1.

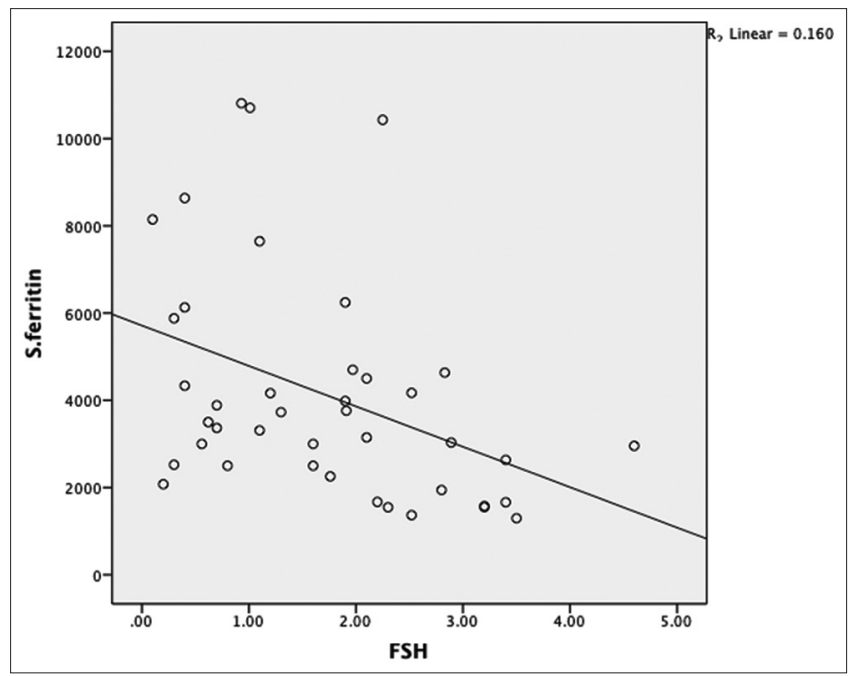

Figure 1: Correlation between serum ferritin and follicle-stimulating hormone, Pearson correlation $=-0.4, p=0.009$

The inverse correlation with Pearson value -0.2 with no significant $p$-value $(0.12)$, was reported between serum ferritin level and LH level, as shown in Figure 2. The significant statistics value of $p=0.025$ for Pearson -0.3 was reported for the correlation between serum ferritin and estrogen, as shown in Figure 3.

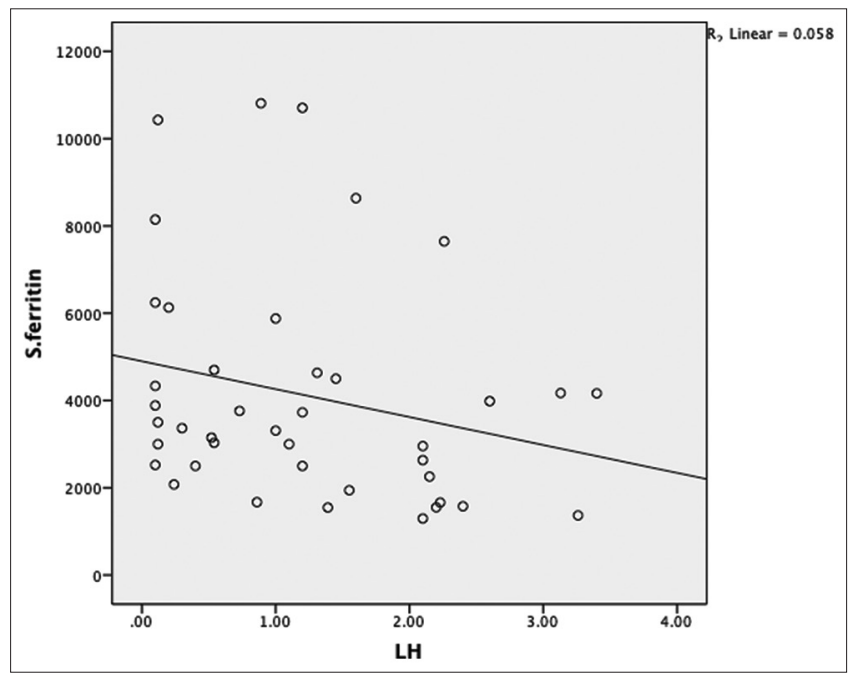

Figure 2: Correlation between serum ferritin and luteinizing hormone level, Pearson correlation $=-0.2, p=0.12$

\section{Discussion}

In this study, the majority thalassemic major female patients suffer from primary amenorrhea $(80.5 \%)$

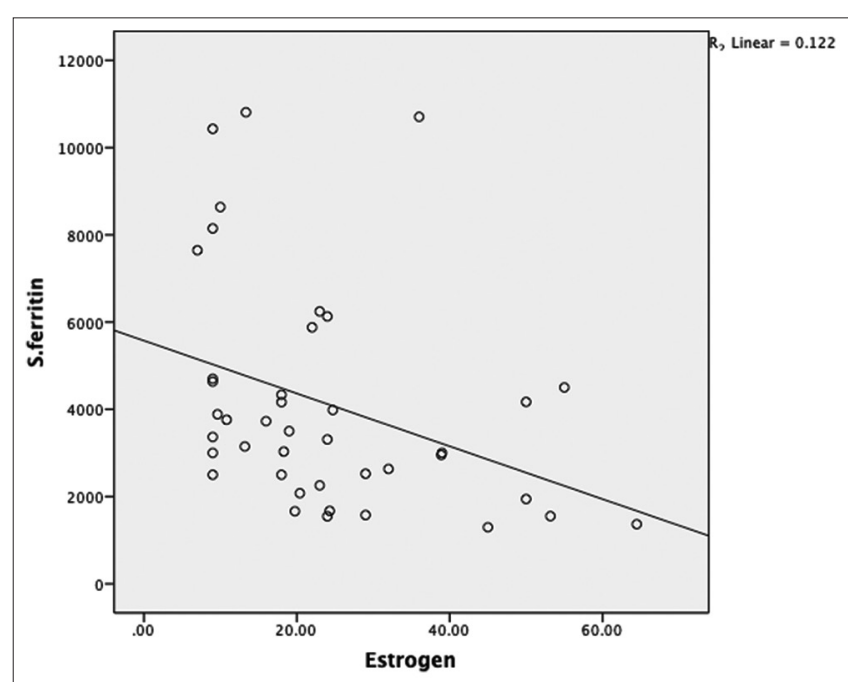

Figure 3: Correlation between serum ferritin and estrogen, Pearson correlation $=-0.3, p$-value $=0.025$

or scanty $(4.9 \%)$ menstrual period which means having great risk for hypogonadism and gonadal failure. In another study, 10 of 11 BTM young patients (90\%) from a developing country were presented with early form of hypogonadism [14].

Another study on 382 BTM patients treated with desferrioxamine at the Thalassemia Center in Dubai showed a significantly lower prevalence of hypogonadism of only $25 \%$ [15].

The high variability in the proportion of patients affected by gonadal failure could be explained by ethnic factors, different availability of therapeutic agents, economic status, and genetic susceptibility [1] (63.4\%) of the studied patients had high ferritin level (more than $3000 \mathrm{ng} / \mathrm{dl}$ ) which had a statistically significantly effect on FSH, LH, and estrogen levels ( $p$-value: 0.001, 0.002, and 0.003 , respectively).

These results were confirmed by finding a statistically significant inverse correlation between ferritin with both FSH (Pearson's correlation [-0.4], p-value 0.0009) and estrogen levels (Pearson's correlation [-0.3], p-value 0.025).

Furthermore, there was an inverse correlation between ferritin and $\mathrm{LH}$ levels (Pearson value -0.2 but with no significant $\mathrm{p}$-value 0.12 ). In the studied patients, it is obvious, when ferritin increase in the body leads to decrease in $\mathrm{FSH}, \mathrm{LH}$, and estrogen.

This inverse relation means the high ferritin level can affect both pituitary and gonads. To differentiate between which happened first, we need to do stimulation test for these patients if still ovulate means the gonads can function.

Further studies and larger sample to identify pituitary with/without gonadal failure with variable severity in thalassemic female. Many studies done reveal the pituitary gland is more likely to be firstly affected by iron overload than the gonads [9]. 
Other study, state "Ovarian reserve is preserved in the majority of female thalassemia patients, even in women with amenorrhea [6]".

The general accepted explanation for variation in the prevalence and severity of hypogonadism in thalassemia major can depend on the age group studied, genotype of thalassemia, extent of transfusion, age at the beginning, and type of iron chelation therapy [7], [8].

These female if not treated early can progress to delaying or absence of other secondary sexual character which ends with failure to get pregnant and become infertile. This affects the quality of life and may lead to many psychological diseases such as anxiety, depression, and low self-steam, especially they can attend schools and colleges with more life expectance.

In this study, the possible explanations for unpleasant results start from the absence of primary prevention for this horrible hereditary disease by doing mandatory $\mathrm{Hb}$ electrophoresis test for the couple who want to marry. The hemoglobin electrophoresis machine available in the major Waist province hospitals but not working because there is no maintenance and deficiency for kits needed for its functioning.

\section{Other local causes}

1. Instability in maintenance, availability, and even quality for both chelating agents (Desferal and $X$ - jade)

2. Instability in the maintenance in biochemical blood tests such as serum ferritin, thyroid function tests, gonadotropin, and gonadal sex hormones that's needed to be done regularly for early detection and required for follow-up after starting hormonal treatment

3. The needs for the presence of female gynecologist to examine pubertal female patients, as the majority of embarrassed and shy to complain from absence, scanty irregularity of their menstrual cycles, and absence of other secondary sexual character. Then, no treatment such as sex steroid or pulsatile $\mathrm{GnRH}$ can be utilized to induce puberty at proper age

4. Patients-related factors.

Poor compliance for chelation therapy, for $\mathrm{X}$ jade: many complain from epigastric pain after taking the dose at the early morning on the empty stomach so they not take it regularly.

For Desferal: In addition to infusion pump technical failure and luck of maintenance, pain, ulcers, infections at site of infusion leads to poor compliance for treatment. In most of patients, poverty, loss of education for patients, and/or their parents greatly affect the compliance and delayed the multisystemic complications detection for this life-long disease.
Other accompanied diseases such as infections (i.e.: HBV, HCV, and HIV), endocrine disorder (i.e.: DM and hypothyroidism), and osteoporosis are other causes that affect the quality of life and may leads to great psychological impacts that affects the compliance for treatment and follow-up. A study in India agree with our results in this study and shows statistically significant low FSH and LH levels as well as significant negative correlation between ferritin and the gonadotrophins in both male and female thalassemic group [6].

The hope is iron-induced hypogonadism may be reversible with intensive iron chelation regimens [10]. In early stages, sex steroid or pulsatile $\mathrm{GnRH}$ can be utilized to induce puberty if the hypothalamic-pituitarygonadal (HPG) axis is functionally intact

Later on, if the HPG axis is irreversibly damaged, sex steroid replacement therapy is the only option to induce puberty [11]. In general, it is advisable to initiate puberty with sex steroid replacement therapy by the age group of 13 years in women [11].

Sex steroids are important for the maintenance of normal body composition, skeletal health and induction, and maturation of secondary sexual characteristics [12].

Limitations of our study include larger sample size was required to improve the statistical importance of this study, other factors can affect the pituitary gonadotropins and gonadal sex steroid such as adipose tissue leptin [13], liver disorders, chronic hypoxia, and zinc deficiency which remains unexplored by us.

\section{Conclusions}

In this study, still pubertal thalassemic female at great risk of gonadal failure with its great side effects on normal body composition, skeletal health, maintaining secondary sexual character, and possible future pregnancy. High ferritin level that precipitates and disrupts the pituitary gonadotropin and gonadal sex steroid cells is a significant risk factor. The needs for more strict iron control, early screening and proper treatment of gonadotropin, and gonadal sex steroid deficiency around the age of 13 years are essential to be offered. More studies and larger sample are needed to confirm and or add other risk factors that contribute in gonadal insufficiency in thalassemic female.

\section{References}

1. Albu Al, Albu D. Hypogonadism in Female Patients with Beta Thalassemia Major. London: IntechOpen; 2018. 
2. De Sanctis V, Elsedfy H, Soliman AT, Elhakim IZ, Soliman NA, Elalaily R, et al. Endocrine profile of ß-thalassemia major patients followed from childhood to advanced adulthood in a tertiary care center. Indian J Endocrinol Metab 2016;20(4):451-9.

PMid:27366710

3. De Sanctis V, Elsedfy H, Soliman AT, Elhakim IZ, Kattamis C Soliman NA, et al. Clinical and biochemical data of adult thalassemia major patients (TM) with multiple endocrine complications (MEC) versus TM patients with normal endocrine functions: A long-term retrospective study (40 years) in a tertiary care center in Italy. Mediterr J Hematol Infect Dis 2016;8(1):e2016022.

PMid:27158435

4. Srisukh S, Ongphiphadhanakul B, Bunnag P. Hypogonadism in thalassemia major patients. J Clin Transl Endocrino 2016;5:42-5.

PMid:29067234

5. Sinharay M, Mitra S, Dasgupta A. Iron overload, gonadotrophins and gonadal sex steroids in thalassemia. Int $\mathrm{J}$ Cur Res Rev. 2017;9(23):16-21.

6. Shamshirsaz AA, Bekheirnia MR, Kamgar M, Pourzahedgilani N, Bouzari N, Habibzadeh M, et al. Metabolic and endocrinologic complications in beta-thalassemia major: A multicenter study in Tehran. BMC Endocrine Disorders. 2003;3(1):4.

PMid:12914670

7. Zervas A, Katopodi A, Protonotariou A, Livadas S, Karagiorga M, Politis $\mathrm{C}$, et al. Assessment of thyroid function in two hundred patients with beta-thalassemia major. Thyoid. 2002;12(2):151-4. PMid:11916284

8. Delvecchio M, Cavallo L. Growth and endocrine function in thalassemia major in childhood and adolescence. J Endocrinol Invest. 2010;33(1):61-8.
PMid:20203539

9. Rifki U, Erdal K, Murat A, Sehmus O, Murat A, Yaren D, et al. A rare presentation of transfusional hemochromatosis: hypogonadotropic hypogonadism. Case Rep Endocrinol2015;2015:493091.

PMid:26266058

10. Modell $B$, Khan M, Darlison M, Westwood MA, Ingram D, Pennell DJ. Improved survival of thalassaemia major in the UK and relation to $\mathrm{T}^{*}$ cardiovascular magnetic resonance. J Cardiovasc Magn Reson. 2008;10(1):42. PMid:18817553

11. Styne DM, Grumbach MM. Physiology and disorders of puberty. In: Williams Textbook of Endocrinology. Amsterdam, Netherlands: Elsevier; 2016. p. 1074-218.

12. De Sanctis V, Borsari G, Brachi S, Govoni M, Carandina G. Spermatogenesis in young adult patients with beta-thalassaemia major long-term treated with desferrioxamine. Georgian Med News 2008;156:74-7. PMid: 18403814

13. Smith JT, Acohido BV, Clifton DK, Steiner RA. KiSS-1 neurones are direct targets for leptin in the ob/ob mouse. J Neuroendocrinol. 2006;18(4):298-303.

PMid:16503925

14. Gulati R, Bhatia V, Agarwal SS. Early onset of endocrine abnormalities in beta-thalassemia major in a developing country. J Pediatr Endocrinol Metab. 2000;13(6):651-69. PMid: 10905390

15. Belhoul KM, Bakir ML, Saned MS, Kadhim AM, Musallam KM, Taher AT. Serum ferritinlevels and endocrinopathy in medically treated patients with $\beta$ thalassemia major. Ann Hematol. 2012;91(7):1107-14.

PMid:22281991 